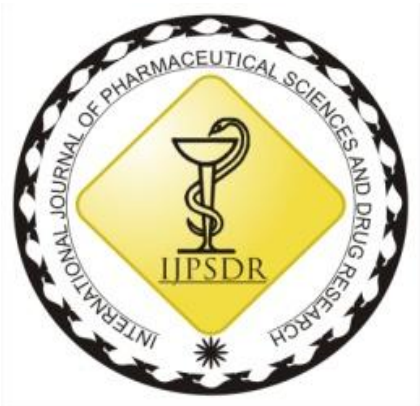

ISSN: 0975-248X

RESEARCH ARTICLE CODEN (USA): IJPSPP

$($ (c) $)$ EY-NC-SA

\title{
Formulation and Evaluation of Herbal Tablet Containing Hydro- alcoholic Extract of Achyranthes aspera Linn. (Roots) Used For the Treatment of Vaginal Infection
}

\author{
Shweta Shriwas ${ }^{1 *}$, Raju Chouksey $^{1}$, Sumeet Dwivedi ${ }^{2}$ \\ ${ }^{1}$ Faculty of Pharmacy, Dr. A. P. J. Abdul Kalam University, Indore, Madhya Pradesh, India \\ ${ }^{2}$ Department of Pharmacognosy \& Biotechnology, Swami Vivekanand College of Pharmacy, Indore, \\ Madhya Pradesh, India
}

Copyright (C) 2019 Shweta Shriwas et al. This is an open access article distributed under the terms of the Creative Commons AttributionNonCommercial-ShareAlike 4.0 International License which allows others to remix, tweak, and build upon the work non-commercially, as long as the author is credited and the new creations are licensed under the identical terms.

\begin{abstract}
Vaginal infection include irritation, itching and swelling are very frequent and common among women due to various un-hygienic issues including a major fungus causing infection is Candida species. According to Ayurveda several herbs are used to cure women disorders, though there proper documentation and validation need to be established. It has increasingly deserved a special attention among the medical community. In spite of the presence of Candida species as a human commensal, alarming rates of local and systemic infections have been observed, varying from moderate to severe impact. The present investigation aims to formulate and evaluate herbal tablet containing hydro-alcoholic extract of Achyranthes aspera Linn. (Roots). Various batches F1 to F8 were prepared using different ratio of ingredients and were evaluated as per IP. The data obtained indicate that F7 have excellent results when compared with other formulation codes.
\end{abstract}

Keywords: Vaginal infection, Achyranthes aspera, Formulation.

*Corresponding author: Mrs. Shweta Shriwas

Address: Faculty of Pharmacy, Dr. A. P. J. Abdul Kalam University, Indore, Madhya Pradesh, India

Tel.: +91-9826497427

E-mail $\bowtie$ : herbal0914@rediffmail.com

Relevant conflicts of interest/financial disclosures: The authors declare that the research was conducted in the absence of any commercial or financial relationships that could be construed as a potential conflict of interest.

Received: 25 June, 2019; Revised: 16 July, 2019; Accepted: 25 July, 2019; Published: 30 July, 2019

\section{INTRODUCTION}

According to NICHD i.e., National institute of Child Health and Human development there are five types of major gynecological disorders associated with females, these include vulvodynia, vaginitis, pelvic floor disorders, pelvic pain and menstrual disorders. In India approximately every women suffers from gynecological disorders such as vaginal infection, menstrual troubles or any other associated disease. The percentage is more in rural women than urban women and the reason behind this is the life style, food habit and un-hygienic conditions in rural areas. [1-2]

During past few years plant derived extracts and their isolated phytochemicals are gaining importance and are also a new emerging area of research. Vaginal infection also referred as vaginitis include irritation, itching and swelling are very frequent and common among women due to various un-hygienic issues 
including a major fungus causing infection is Candida species. Candida, a fungus is very often associated with the vaginal infections. In fact, Candida species have been implicated in an onset of mild and severe clinical conditions, although it was considered a commensal microorganism of healthy individuals. ${ }^{[3-5]}$ Achyranthes aspera Linn. commonly known as chirchira belongs to family Amaranthaceae is traditional herbal drugs used in the treatment of women disorders from ancient. Part of selected is used for the treatment of inflammation, bacterial infection, fungal infection etc. especially concerned to women disorders. ${ }^{[6]}$ Keeping this concept in mind the present study was designed to formulate and evaluate herbal tablet containing hydroalcoholic extract of Achyranthes aspera Linn. (Roots).

\section{MATERIALS AND METHODS}

\section{Selection of plant material}

The herb viz., Achyranthes aspera Linn. (Roots) ASR, used in the treatment of gynecological disorders was selected based on the traditional claims as mentioned in folk-lore. The above mentioned herbs are widely used in traditional medicine for the treatment of gynecological disorders.

Collection and authentication of plant/plant material The plant material selected for the present investigation viz., Achyranthes aspera Linn. (Roots) ASR, was collected in the months of Dec' 2016 to Jan, 2017 from various sites of Malwa region of Madhya Pradesh and identified \& authenticated by Dr. S. N. Dwivedi, Professor and Head, Department of Botany, Janata PG College, A.P.S. University, Rewa, (M.P.) and was deposited in our Laboratory, Voucher specimen No. P/AS-R/1812.

\section{Extraction of Plant material}

$250 \mathrm{~g}$ of the air dried coarsely powdered roots of Achyranthes aspera Linn. (ASR) was placed in soxhlet apparatus and was extracted with ethanolic and hydroalcohol [water: ethanol (70:30)] until the extraction was completed. After extraction, the filtrate was evaporated to get the extract. ${ }^{[7]}$

Plant extracts

The hydro-alcoholic extracts of dried plant material of Achyranthes aspera Linn. (Roots) were taken for formulation of herbal tablets.

\section{Compatibility studies}

It was carried out by FTIR using drug and excipients (1:1).

Pre formulation studies (Pre compression studies) blended [8-12]

Standard protocols and procedures were adopted for determination of Bulk density, Tapped density, Compressibility index (Carr's index), Hausner's ratio and Angle of repose.

\section{Preparation of herbal tablet}

The herbal tablets were prepared by direct compression technique using hydro-alcoholic extracts of dried plant material of Achyranthes aspera Linn. (Roots) ASR and different proportion of excipients. The compositions of various formulations were mentioned in table 3 . All the ingredients used in the present investigation to formulate herbal tablet were passed through mesh no 100. The flow properties were determined for all the mixtures; the powder mixtures possess good flow properties and good packing ability. The mixture were directly compressed each of $300 \mathrm{mg}$ in weight using a 10 station Mini Press-I rotary tablet compression machine which was fitted with $6 \mathrm{~mm}$ flat shaped punches. After punching the tablets were observed for tablet defects like capping, lamination \& chipping, no any tablet defects were observed. [13]

Table 1: Grading of powders for their flow properties

\begin{tabular}{cc} 
Table 1: Grading of powders for their flow properties \\
\hline Carr's index & Flow \\
\hline $5-15$ & Excellent \\
$15-16$ & Good \\
$18-21$ & Fair to Passable \\
$23-25$ & Poor \\
$33-38$ & Very Poor \\
$<40$ & Very very poor \\
\hline
\end{tabular}

Table 2: Relation between angle of repose and powder flow

\begin{tabular}{cc} 
Table 2: Relation between angle of repose and powder flow \\
\hline Carr's index & Flow \\
\hline$<25$ & Excellent \\
$25-30$ & Good \\
$30-40$ & Passable \\
$>40$ & Very poor \\
\hline
\end{tabular}

Table 3: Formulation of herbal tablet containing hydro-alcoholic extract of Achyranthes aspera Linn. (Roots) ASR

\begin{tabular}{ccccccccc}
\hline \multirow{2}{*}{ Ingredients } & \multicolumn{7}{c}{ Formulation Code (HAEASR) } \\
\cline { 2 - 9 } & F1 & F2 & F3 & F4 & F5 & F6 & F7 & F8 \\
\hline HAEASR & 150 & 150 & 150 & 150 & 150 & 150 & 150 & 150 \\
$\begin{array}{c}\text { Spray dried } \\
\text { lactose }\end{array}$ & 126 & 123 & 120 & 117 & 126 & 123 & 120 & 117 \\
$\begin{array}{c}\text { Acacia } \\
\text { Talc }\end{array}$ & 10 & 10 & 10 & 10 & 10 & 10 & 10 & 10 \\
$\begin{array}{c}\text { Potato starch } \\
\text { Sodium }\end{array}$ & - & - & - & - & 6 & 9 & 12 & 15 \\
$\quad$ starch & 6 & 9 & 12 & 15 & - & - & - & - \\
glycolate & & & & & & & & \\
Mg stearate & 5 & 5 & 5 & 5 & 5 & 5 & 5 & 5 \\
Total weight & 300 & 300 & 300 & 300 & 300 & 300 & 300 & 300 \\
\hline All values are taken in $\mathrm{mg}$ & & & & & &
\end{tabular}

\section{RESULTS AND DISCUSSION}

The investigation of the efficiency of plant extract and their formulations in induced systemic and local infection model is of quite interesting. There are several mimics that the real conditions of infected organism and at the same time the achievements of the direct effects of the extract. Several scholars have evaluated the effects of plant extracts along with their formulations in systemic infections and in inducted vaginal infection. It was also noted that now-a-days there are several herbal formulations are in the market used for the vaginal infection and they having very less or no adverse/side effects. The present work was undertaken to formulate and evaluate herbal tablet containing hydro-alcoholic extract of Achyranthes aspera Linn. (Roots). The selected hydro-alcoholic extract viz., HAEASR Achyranthes aspera Linn. (Roots) along with various excipients selected were mixed according to the 
formula mentioned and various pre-formulation parameters were evaluated. In this study bulk density, tapped density, Carr's index, Hausner's ratio and angle of repose were recorded. The data were presented in table 4 . It was revealed from the present study that all the studied parameters were within limit as per IP. The FTIR study was carried out and it was concluded that no any drug-excipients incompatibility has been observed.

Table 4: Pre-formulation studies of formulation containing hydroalcoholic extract of Achyranthes aspera Linn. (Roots) ASR

\begin{tabular}{cccccc}
\hline \multirow{2}{*}{$\begin{array}{c}\text { Formulation } \\
\text { Code }\end{array}$} & $\begin{array}{c}\text { Bulk } \\
\text { density }\end{array}$ & $\begin{array}{c}\text { Tapped } \\
\text { density }\end{array}$ & $\begin{array}{c}\text { Hausner's } \\
\text { ratio }\end{array}$ & $\begin{array}{c}\text { Carr's } \\
\text { index }\end{array}$ & $\begin{array}{c}\text { Angle } \\
\text { of } \\
\text { repose }\end{array}$ \\
\hline F1 & 0.476 & 0.578 & 1.21 & 17.64 & 21.38 \\
F2 & 0.482 & 0.564 & 1.17 & 14.53 & 22.82 \\
F3 & 0.462 & 0.51 & 1.10 & 9.41 & 21.20 \\
F4 & 0.421 & 0.511 & 1.21 & 17.61 & 24.83 \\
F5 & 0.472 & 0.528 & 1.11 & 10.60 & 24.91 \\
F6 & 0.478 & 0.515 & 1.07 & 7.18 & 22.43 \\
F7 & 0.489 & 0.52 & 1.06 & 5.96 & 23.18 \\
F8 & 0.423 & 0.501 & 1.18 & 15.56 & 23.94 \\
\hline
\end{tabular}

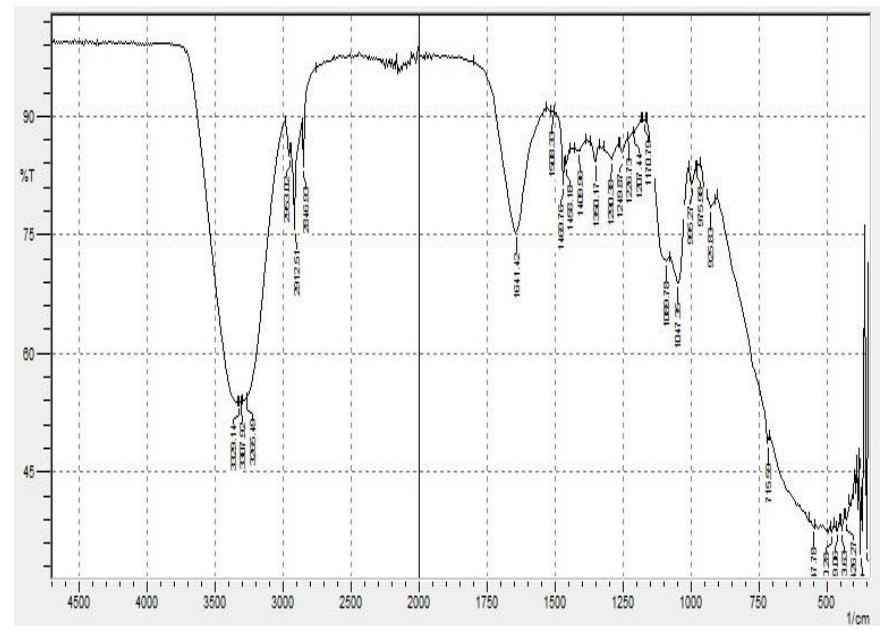

Fig. 1: FTIR curve of Achyranthes aspera Linn. (Roots)

Table 5: Organoleptic properties of formulation containing hydroalcoholic extract of Achyranthes aspera Linn. (Roots) ASR

\begin{tabular}{|c|c|c|c|}
\hline \multirow{2}{*}{$\begin{array}{l}\text { Formulation } \\
\text { Code }\end{array}$} & \multicolumn{3}{|c|}{ Parameters } \\
\hline & Color & Odor & Taste \\
\hline \multicolumn{4}{|c|}{ HAEASR } \\
\hline F1 & Brown & Pleasant & Acceptable \\
\hline F2 & Brown & Pleasant & Acceptable \\
\hline F3 & Brown & Pleasant & Acceptable \\
\hline F4 & Brown & Pleasant & Acceptable \\
\hline F5 & Brown & Pleasant & Acceptable \\
\hline F6 & Brown & Pleasant & Acceptable \\
\hline F7 & Brown & Pleasant & Acceptable \\
\hline F8 & Brown & Pleasant & Acceptable \\
\hline
\end{tabular}

The formulated herbal tablets containing hydroalcoholic extracts of dried plant material of Achyranthes aspera Linn. (Roots) were evaluated as per IP. In all the batches no any tablet defects were recorded. The organoleptic properties such as color, odor, taste for all the five different types of formulation and their batches were recorded and were presented in table 5 . The hardness, friability \& weight variation for all the batches was recorded and result indicated that for all the batches it was within the limit (Table 6). The disintegration times for all the batches were recorded and it was found that the range of DT was from 9.08 to $18.23 \mathrm{mts}$ (Table 7). The drug content was found maximum in F7 i.e., $100.02 \%$ and minimum $96.92 \%$ (Table 7). The results of drug release profile indicate that the formulation F7 has maximum release of $98.31 \%$ at 30 mts (Table 8, Fig. 2).

Table 6: Evaluation parameters of formulation containing hydroalcoholic extract of Achyranthes aspera Linn. (Roots) ASR

\begin{tabular}{|c|c|c|c|}
\hline \multirow{2}{*}{$\begin{array}{l}\text { Formulation } \\
\text { Code }\end{array}$} & \multicolumn{3}{|c|}{ Parameters } \\
\hline & $\begin{array}{c}\text { Hardness } \\
\left(\mathrm{kg} / \mathrm{cm}^{2}\right)\end{array}$ & $\begin{array}{c}\text { Friability } \\
(\%)\end{array}$ & $\begin{array}{c}\text { Weight } \\
\text { variations }\end{array}$ \\
\hline \multicolumn{4}{|c|}{ HAEASR } \\
\hline F1 & $4.98 \pm 0.23$ & $0.67 \pm 0.02$ & \pm 3.87 \\
\hline $\mathrm{F} 2$ & $4.90 \pm 0.22$ & $0.83 \pm 0.01$ & \pm 4.12 \\
\hline F3 & $4.95 \pm 0.01$ & $0.91 \pm 0.10$ & \pm 2.98 \\
\hline $\mathrm{F} 4$ & $4.69 \pm 0.05$ & $0.68 \pm 0.03$ & \pm 3.10 \\
\hline F5 & $4.95 \pm 0.67$ & $0.59 \pm 0.15$ & \pm 3.28 \\
\hline F6 & $4.80 \pm 0.03$ & $0.73 \pm 0.01$ & \pm 3.81 \\
\hline F7 & $4.15 \pm 0.28$ & $0.88 \pm 0.17$ & \pm 3.86 \\
\hline F8 & $4.29 \pm 0.21$ & $0.81 \pm 0.01$ & \pm 3.81 \\
\hline
\end{tabular}

Table 7: Disintegration time and drug content of formulation containing hydro-alcoholic extract of Achyranthes aspera Linn. (Roots) ASR

\begin{tabular}{ccc}
\hline \multirow{2}{*}{$\begin{array}{c}\text { Formulation } \\
\text { Code }\end{array}$} & \multicolumn{2}{c}{ Parameters } \\
\cline { 2 - 3 } & $\begin{array}{c}\text { Disintegration time } \\
\text { (mts) }\end{array}$ & Drug content (\%) \\
\hline \multicolumn{3}{c}{ HAEASR } \\
\hline F1 & $13.45 \pm 0.14$ & 96.92 \\
F2 & $18.23 \pm 0.03$ & 97.11 \\
F3 & $10.61 \pm 0.01$ & 96.30 \\
F4 & $12.62 \pm 0.01$ & 96.25 \\
F5 & $14.27 \pm 0.76$ & 97.81 \\
F6 & $9.08 \pm 0.28$ & 98.43 \\
F7 & $11.04 \pm 0.31$ & 100.02 \\
F8 & $12.04 \pm 0.06$ & 98.62 \\
\hline
\end{tabular}

Table 8: In-vitro drug release of formulation containing hydroalcoholic extract of Achyranthes aspera Linn. (Roots) ASR

\begin{tabular}{|c|c|c|c|c|c|c|c|c|c|}
\hline \multirow{2}{*}{$\begin{array}{l}\text { S. } \\
\text { N } \\
\text { o. }\end{array}$} & \multirow{2}{*}{$\begin{array}{c}\text { Tim } \\
\text { e } \\
\text { (Mt } \\
\text { s) }\end{array}$} & \multicolumn{8}{|c|}{ \% Drug Release } \\
\hline & & F1 & F2 & F3 & F4 & F5 & F6 & F7 & F8 \\
\hline 1 & 0 & 0 & 0 & 0 & 0 & 0 & 0 & 0 & 0 \\
\hline \multirow{2}{*}{2} & \multirow{2}{*}{10} & 19.3 & 22.9 & 24.3 & 23.9 & 27.4 & 29.1 & 32.1 & 30.2 \\
\hline & & 4 & 6 & 9 & 1 & 1 & 6 & 6 & 6 \\
\hline \multirow{2}{*}{3} & \multirow{2}{*}{20} & 57.2 & 61.2 & 62.9 & 60.2 & 65.2 & 67.0 & 68.4 & 65.1 \\
\hline & & 8 & 8 & 1 & 9 & 6 & 1 & 3 & 9 \\
\hline \multirow{2}{*}{4} & \multirow{2}{*}{30} & 89.7 & 90.8 & 92.6 & 91.0 & 93.1 & 95.2 & 98.3 & 96.3 \\
\hline & & 1 & 1 & 8 & 2 & 9 & 1 & 1 & 0 \\
\hline
\end{tabular}

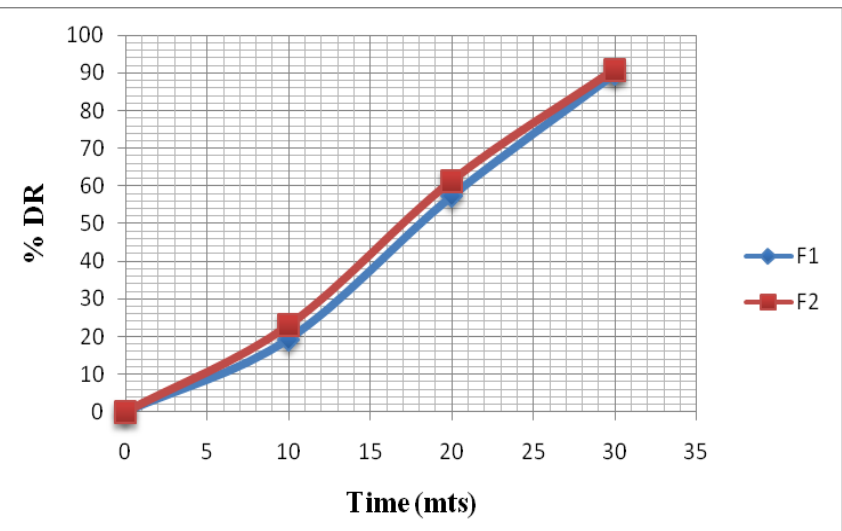




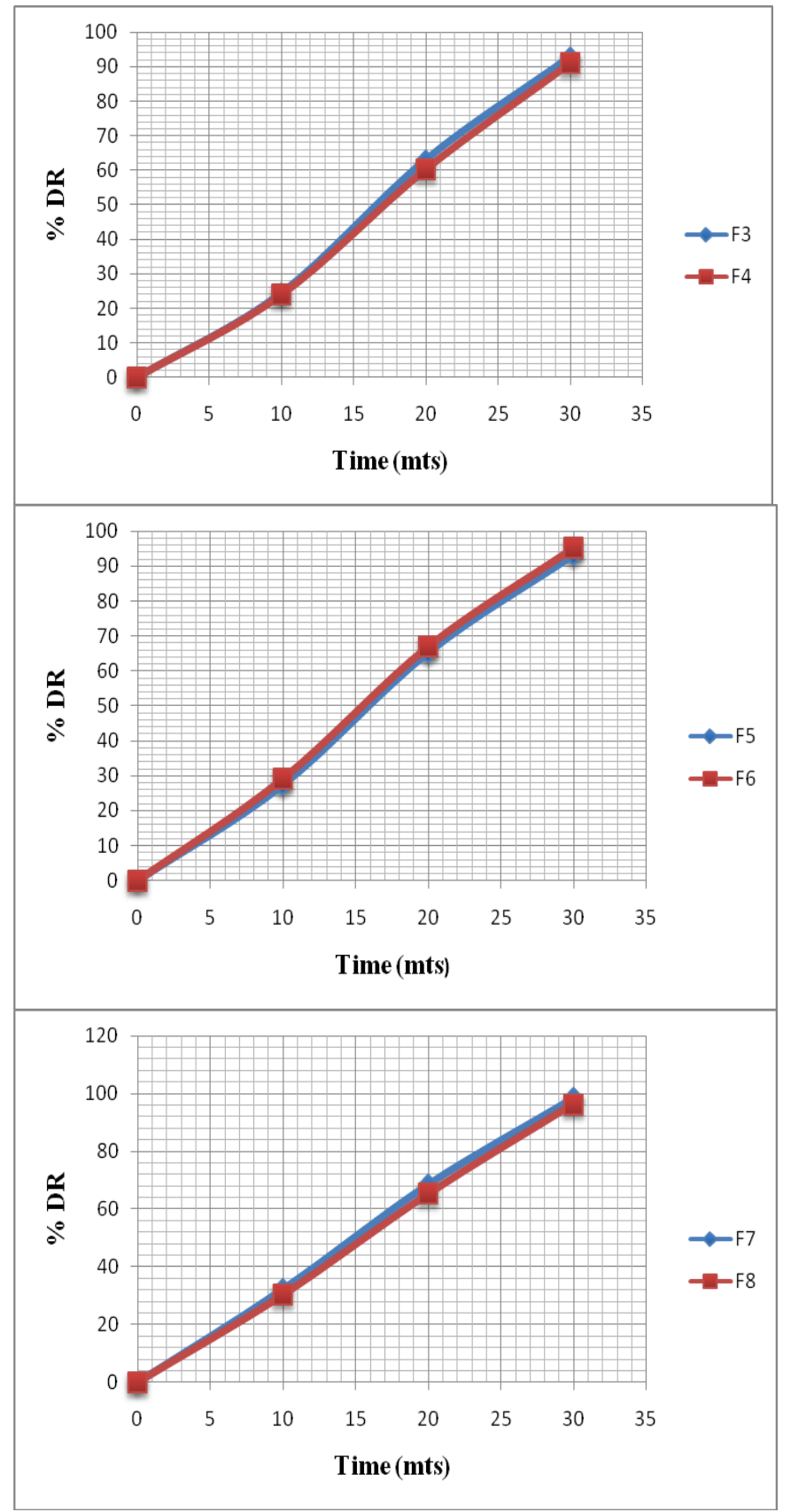

Fig. 2: Drug release of formulation containing hydro-alcoholic extract of Achyranthes aspera Linn. (Roots) ASR

It was found that the hydro-alcoholic extract of selected herbs Achyranthes aspera Linn. (Roots) have effective results when formulated in the form of tablet. The formulation code F7 has promising and effective drug content and release. Thus, from the present investigation it was concluded that the herbs selected will have a prominent effect in the treatment of vaginal infection, though the pharmacological screening and clinical approaches need to establish for the formulation of safe and effective herbal drugs.

\section{REFERENCES}

1. Lakshmi V, Gupta RK. Ayurvedic preparations and gynaecological disorders. International Journal of Ayurveda \& Alternative Medicine. 2014; 5(2):10-14.

2. Dwivedi S, Tripathi R, Dwivedi SN. Ethno-medicinal plants used to treat gynecological disorders by tribal people of Madhya Pradesh, India. International Journal of Pharmacy and Life Sciences. 2010; 1(3): 160-169.

3. Palombo EA. Traditional medicinal plant extracts and natural products with activity against oral bacteria: potential application in the prevention and treatment of oral diseases. Evidence-Based Complementary and Alternative Medicine. 2011, Article ID 680354, 15.

4. Sher A. Antimicrobial activity of natural products from medicinal plants. Gomal Journal of Medical Sciences. 2009; 7(1): 72-78, 2009.

5. Rubió L, Motilva MJ, Romero MP. Recent advances in biologically active compounds in herbs and spices: a review of the most effective antioxidant and anti-inflammatory active principles. Critical Reviews in Food Science and Nutrition. 2013; 53(9): 943-953.

6. Dwivedi S. Status survey of medicinal plants wealth of Malwa region of Madhya Pradesh with special reference to conservation of vulnerable and endangered species. J. Econ. Taxon. Bot. 2009; 33(2): 443-452.

7. Harborne JB. Phytochemical methods, Chapman and Hall, 1984, Ist Edition, London.

8. Mishra US, Murthy PN, Pasa G, Mishra D. Formulation development and evaluation of herbal tablet containing methanolic extract of Butea frondosa, Int. J. of Inst. Pharm. and Life Sci. 2011 1(3):1-15.

9. Lachman L, Liberman HA, Kanig JL. The Theory and Practice of Industrial Pharmacy, $3^{\text {rd }}$ ed., Varghese publishing House Bombay, 1999; 443-453.

10. Subrahmanyam CVS. Text Book of Physical Pharmaceutics, $2^{\text {nd }}$ Edn. 2001, Vallabh Prakashan, New Delhi, pp. 253-261.

11. Aulton ME. Pharmaceutics: The Science of Dosage Form Design. 2nd ed. 2002, Churchill Livingstone, London, pp. 322 334.

12. Costa P, Lobo J, Manuel S. Modeling and comparison of dissolution profile. Eur. J. of Pharm. Sci. 2001; 13:123-133.

13. Dwivedi S. Development of standardization parameters of Guizotia abyssinica (L.f.) Cass with special reference to its pharmacological approaches, Ph.D., Thesis 2015, SGVU, Jaipur.

HOW TO CITE THIS ARTICLE: Shriwas S, Chouksey R, Dwivedi S. Formulation and Evaluation of Herbal Tablet Containing Hydro-alcoholic Extract of Achyranthes aspera Linn. (Roots) Used For the Treatment of Vaginal Infection. Int. J. Pharm. Sci. Drug Res. 2019; 11(4): 137-140. DOI: 10.25004/IJPSDR.2019.110406 